\title{
Okul Danışmanlarının Psikolojik İyi Oluşları Üzerinde Psikolojik Sermaye ve Başa Çıkma Tarzlarının Rolü
}

\section{The Role of Psychological Capital and Coping Styles on the Psychological Well-Being of School Counselors}

\author{
Hatice ODACI ${ }^{1}$, Nihal TOPAL ${ }^{2}$, Şükrü ÖZER ${ }^{3}$
}

\begin{abstract}
${ }^{1}$ Prof. Dr., Psikoloji Bölümü, Edebiyat Fakültesi,Karadeniz. Teknik Üniversitesi,TÜRKIYY, hatodaci@hotmail.com, (https://orcid.org/0000-0002-2080-6269)

${ }^{2}$ Uzman, Akçaabat Cumhuriyet Ortaokulu, MEB, TÜRKIYE, nihaltopal61@gmail.com, (https://orcid.org/0000-0001-6466-6651)

${ }^{3}$ Sorumlu Yazar, Uzman, Osman Kalyoncu IHO, MEB, TÜRKIYE, sukru_ozer@hotmail.com, (https://orcid.org/0000-0001-7714-9581)
\end{abstract}

Geliș Tarihi: 10.05.2021

Kabul Tarihi: 26.11 .2021

ÖZ

Bu çalışmanın amacı, okul psikolojik danışmanlarının psikolojik iyi oluşları üzerinde psikolojik sermaye ve başa çıkma tarzlarının rolünü belirlemektir. İlişsisel araştırma modeline göre tasarlanan bu çalışmanın örneklemi gönüllü olarak katılım sağlayan 157 kadın ve 57 erkek toplam 214 psikolojik danışmandan oluşmaktadır. Araştırmada veriler Demografik Bilgi Formu, Mental İyi Oluş Ölçeği (Keldal, 2015), Örgütsel Psikolojik Sermaye Ölçeği (Çetin ve Basım, 2012) ve Stresle Başa Çıkma Tarzları Ölçeği (Şahin ve Durak, 1995) kullanılarak elde edilmiştir. Verilerin analizinde Pearson momentler çarpımı korelasyon tekniği ve hiyerarşik regresyon analizi kullanılmıştır. Araştırma bulgularına göre okul danışmanlarının psikolojik iyi oluşları ile iyimserlik, psikolojik dayanıklılık, umut, öz yeterlik, kendine güvenli yaklaşım ve iyimser yaklaşım arasında pozitif yönde; çaresiz yaklaşım ve boyun eğici yaklaşım ile negatif yönde anlamlı ilişkiler belirlenmiştir. Çalışmada son olarak iyimserlik, umut, öz yeterlik, kendine güvenli yaklaşım ve iyimser yaklaşımın psikolojik iyi oluşun önemli yordayıcıları olduğu; psikolojik dayanıklılık, sosyal destek arama, çaresiz yaklaşım ve boyun eğici yaklaşımın ise modele katkısının anlamsız olduğu sonucuna ulaşılmıştır.

Anahtar Kelimeler: Psikolojik danışman, psikolojik iyi oluş, psikolojik sermaye, başa çıkma tarzları.

\begin{abstract}
The aim of this study is to determine the role of psychological capital and coping styles on the psychological well-being of school counselors. The sample of this study, which was designed according to the relational research model, consists of a total of 214 psychological counselors, 157 women and 57 men, who participated voluntarily. The data in the study were obtained by using the Demographic Information Form, the Mental Well-Being Scale (Keldal, 2015), the Organizational Psychological Capital Scale (Çetin ve Basım, 2012) and the Styles of Coping with Stress Scale (Şahin ve Durak, 1995). Pearson product-moment correlation technique and hierarchical regression analysis were used in the analysis of the data. According to the research findings, there is a positive relationship between school counselors' psychological well-being and optimism, resilience, hope, self-efficacy, self-confident approach and optimistic approach; negative significant relationships were determined with the helpless approach and the submissive approach. Finally, it was found that optimism, hope, self-efficacy, selfconfident approach and optimistic approach were important predictors of psychological well-being; it was
\end{abstract}


concluded that the contribution of psychological resilience, seeking social support, helpless approach and submissive approach to the model was meaningless.

Keywords: Psychological counselor, psychological well-being, psychological capital, coping styles.

\section{GíRIŞ}

Okul öncesinden başlayarak her eğitim kademesinde istihdamı sağlanan okul psikolojik danışmanları, resmi sorumlulukları ve rolleri gereği eğitim sisteminin önemli bir parçasıdır. İlgili otoriteler tarafından görev kapsamı açıkça bildirilen bu meslek, öğrenciler ve okulun ihtiyaçlarına karşı her zaman duyarlı ve dinamik olmayı, aynı zamanda da öğretmen, veli ve okul yöneticileriyle işbirliği yapmayı gerektirmektedir (American School Counselor Association [ASCA], 2010). Okul danışmanları öğrencilerin akademik, kariyer ve sosyalduygusal alanlardaki ihtiyaçlarını göz önüne alarak danışmanlık hizmeti sunmanın yanında planlama, oryantasyon, konsültasyon, öğrenciyi tanıma, müşavirlik, sevk ve izleme gibi temel çalışmalardan da aynı anda sorumludur (Milli Eğitim Bakanlığı [MEB], 2020). Temelde öğrencilerin ruh sağlıklarını desteklemekle görevlendirilmiş okul danışmanları (King White, 2019; O'Connor ve Coyne, 2016), sorumluluk alanlarındaki iş ve işlemleri yerine getirirken eğitim dönemini takip eden kapsamlı bir program aracılığıyla çalışmalarını yürütürler. Eğitim ve öğretim faaliyetlerinin tüm unsurlarını kapsayan bu alanın eğitim sisteminin omurgası ve ayrılmaz bir parçası olduğu düşünülebilir.

Gelişimsel, önleyici ve iyileştirici hizmetleri birlikte yürütmeye çalışan okul danışmanları işyerlerinde bir takım sorunlarla karşılaşabilmektedir. Bu sorunların başını okul yöneticilerinin danışmanlara yönelik tutumları çekmekte ve bu durum yönetici-danışman geriliminin kaynağını oluşturmaktadır (Perusse, Goodnough, Donegan ve Jones, 2004). Pratikteki uygulama sonuçları ve bazı araştırma bulguları gösteriyor ki okul danışmanları okul yöneticilerinin tutumlarına bağlı olarak zaman zaman görev tanımlamalarında yer almayan boş derse girme, nöbet tutma ve sekreteryalık gibi tutarsız rollerle görevlendirilmektedir (Culbreth, Scarborough, Banks Johnson ve Solomon, 2005; Monteiro Leitner, Asner Self, Milde, Leitner ve Skelton, 2006). Artan sorumlulukla birlikte danışmanlar öğrencilere doğrudan hizmet edebilmek için yeterli zaman bulmakta zorlanmaktadırlar (Carlson ve Kees, 2013). Hem görev kapsamında yer alan hem de yöneticilerin atadığı görevleri yerine getirmeye çalışan danışmanların diğer okul çalışanları tarafından önyargıyla karşılanmaları ve işbirliği konusunda gerekli desteği bulamamaları sorunların başka bir boyutunu oluşturmaktadır (Parmaksız ve Gök, 2018). Etik kuralların dışında kalan bu uygulama, tutum ve davranışların; okul danışmanlarının psikolojik iyi oluşları üzerinde olumsuz etki bırakarak görevlerinde başarılı olmalarını engellediği savunulabilir. Yüzlerce öğrenci ve veliye karşı sorumlu olduğu alanlar düşünüldüğünde, okullarda psikolojik danışmanlık görevini yerine getiren meslek elemanlarının psikolojik iyilik hâllerinin incelenmesi önemli ve gerekli hâle gelmiştir. Bu araştırma, okul danışmanlarının psikolojik sermaye düzeyleri ve başa çıkma tarzlarının psikolojik iyi oluşları üzerinde nasıl rol oynadığını incelemeyi amaçlamaktadır.

\subsection{Psikolojik İyi Oluş}

En genel anlamıyla psikolojik iyi oluş, insanların yaşamları ve davranışları üzerinde anlamlı bir kontrole sahip olduklarını hissetme derecesini ifade eder (Ryff, 1989). Pozitif psikolojinin önemli bir belirleyeni durumunda olan iyi oluş, "hedonik" ve "eudaimonik" olmak üzere iki farklı biçimde değerlendirilmektedir. Öznel iyi oluş olarak da adlandırılan hedonik yaklaşım, kişinin olumsuz duygulardan ziyade olumlu olanları daha sıklıkla deneyimlemesi ve yüksek bir yaşam doyumuna sahip olmasını ifade ederken; eudaimonik yaklaşım öznel iyi oluştan bağımsız olan psikolojik iyi oluşu ifade eder ve bireyin kendi kapasitesini geliştirebilme potansiyeline odaklanır (Deci ve Ryan, 2008). Psikolojik iyi oluş durumu bireyin kendini her zaman iyi hissetmesi değil, hayatın normal bir parçası olan hayal kırıklığı ve başarısızlık gibi acı 
verici duyguların yönetilebilmesidir (Huppert, 2009). Ryff ve Singer (2006); olumlu psikolojik ögelere vurgu yapan çok faktörlü bir iyi oluş modelini öne sürmüşlerdir. Tüm boyutların birleşimi kendi sınırlarını geliştirebilen, hem kendiyle hem de çevresindekilerle uyum gösteren, dış şartlar üzerinde kontrol sahibi olan yani yüksek bir psikolojik iyi oluş düzeyindeki bireyi temsil eder. Bu iyi oluşu sürdürmek olumsuz psikolojik durumları ortadan kaldırmayla değil ancak olumlu olanları geliştirmekle mümkündür. Psikolojik iyi oluşun yokluğu ise gelecekteki zorlu yaşam olaylarına karşı bireyleri savunmasız bırakır.

Çocuk ve ergen psikolojisine ilişkin çok yönlü hizmetler sunan okul danışmanları için psikolojik iyi oluş önemli bir unsurdur ve danışmanların kendi psikolojik sağlıklarını korumalarında bir gereklilik olarak karşımıza çıkmaktadır. Psikolojik iyi oluş düzeyi yüksek ve mental sağlığı iyi olan danışmanların danışanlarına yardımcı olma olasılıkları daha yüksektir (Lawson ve Myers, 2011; Tan ve Chou, 2017) ve bu iyi olma hâli korunmadığında danışanların zarar görmesi söz konusu olabilir. Öyle ki; bireylerin iyi oluşlarının düzenleyicisi olarak belirlenen danışmanlık hizmetlerinin (Duarte, 2017) en etkili şekilde sunulması, danışmanların kendi iyilik hâllerini koruyabilmelerine bağlıdır. Dolayısıyla, psikolojik iyi oluş hâlinin korunması danışmanlık hizmeti sunan uzmanlar için hayati bir önem taşımakta (Aydın ve Odac1, 2020a) ve klinik becerilerin kullanılmasını desteklemektedir.

İyi oluşun ruh sağlığı üzerinde de önemli etkileri söz konusudur. Artan psikolojik iyi oluşla birlikte yaşam doyumu da artış gösterirken (Park ve Jeong, 2015), depresyon ve anksiyete gibi depresif belirtiler azalmaktadır (Ryff ve Singer, 2006). Dünya Sağlık Örgütü'ne (2004) göre kötü ruh sağlığı, çalışanların tükenmişlik yaşamalarına sebebiyet vermekte ve iş yaşamlarına katkıda bulunma yetenekleri de sınırlamaktadır. Psikolojik iyi oluş halinin iş yaşantısı üzerinde farklı yansımaları söz konusudur. Araştırmalar psikolojik iyi oluşun; iş stresi, iş doyumu, iş performansı ve iş tükenmişliği gibi bireylerin mesleki yaşantılarını betimleyen önemli değişkenlerle ilişkili olduğunu (Çankır ve Şahin, 2018; Lizano, 2015, s.169; Wright ve Cropanzano, 2000) ve gerçekleştirilen işin anlamlı bulunmasında önemli bir yordayıcı (Keleş, 2017) olduğunu göstermektedir. Ruh sağlığı alanında çalışan uzmanların tükenmişlik düzeylerini ele alan bir meta-analiz çalışması profesyonel tükenmişliğin $\% 40$ düzeyinde olduğu sonucunu ortaya koymuştur (O'Connor, Muller, Neff ve Pitman, 2018). Alan çalışanlarının neden bu kadar yoğun tükenmişlik yaşadıklarını irdeleyen araştırmacılar iş yüküyle ilişkili bulgulara ulaşmışlardır. Yüksek danışan sorumluluğu (Ducharme, Knudsen ve Roman, 2007), ek evrak işleri ve idarecilerin talepleri (McCarthy, Kerne, Calfa, Lambert ve Guz-má n, 2010), öğrencilere yönelik yetersiz bireysel danışma hizmeti sunma (Mullen ve Gutierrez, 2016) ve mesleki rollerin belirsizliği (Young ve Lambie, 2007) danışmanların iş yüklerini arttıran ve tükenmişliklerini olumsuz etkileyen durumlardandır. $\mathrm{Bu}$ yüklü görevleri yerine getirmeye çalışırken danışmanlık potansiyellerini tam olarak ortaya koymakta zorlanan uzmanlar hem mesleklerinden (Aydın ve Odacı, 2020b) hem de mesleki öz yeterliklerinin zarar görmesine bağlı olarak yaşamdan daha az doyum sağlamaktadırlar (Aydın, Odacı ve Kahveci, 2017). Bu etkenlere bağlı olarak, okul danışmanlarının tükenmişliklerini önlemenin yollarından biri psikolojik iyi olma hâlini korumalarından geçmektedir (Kim ve Lambie, 2018). Bazı araştırmacılar psikolojik iyi oluşun korunmasında psikolojik sermayenin anahtar bir rolü olduğunu vurgulamaktadır (Hernández Varas, Labrador Encinas ve Méndez Suárez, 2019).

\subsection{Psikolojik İyi Oluş ve Psikolojik Sermaye}

Bireyin pozitif psikolojik gelişim durumunu tanımlayan psikolojik sermaye (Luthans, Youssef Morgan ve Avolio, 2015); umut, iyimserlik, psikolojik dayanıkl1lık ve öz-yeterlikten oluşan alt faktörlerin toplamını içermektedir (Luthans, Avolio, Avey ve Norman, 2007). İyimserlik, insanların gelecekleri için genelleştirilmiş olumlu beklentilere sahip olma derecesini yansitan bireysel bir farklılık değişkenidir (Carver, Scheier ve Segerstrom, 2010). Öz-yeterlik ise Bandura (1977) tarafından, bireylerin önemli yaşam olayları karşısında etkili yollar üretme kapasitelerine ilişkin inançları olarak ifade edilmiştir. İstenen hedeflere giden yolları belirlemek ve bu yolları kullanmak için bireyin kendini motive etmede algıladığı yeteneği umudu temsil 
ederken (Synder, 2002); psikolojik dayanıklılık, engellerle karşılaşıldığında bireyin baş etme becerileri olarak görülmektedir (Luthans ve diğerleri, 2007). Psikolojik sermayenin çalışanların pozitif örgüt davranışları (iş performansı, doyum, örgüt kültürü, örgütsel destek vb.) üzerinde hem doğrudan hem de dolaylı etkileri mevcuttur (Avey, Reichard, Luthans ve Mhatre, 2011; Çavmak ve Acar, 2020). Pozitif psikolojinin odaklandığı örgütsel psikolojik sermaye ile iyi oluş, pek çok araştırmacının ilgisini çekmiş ve elde edilen bulgular iki pozitif değiş̧en arasında olumlu ilişkiler belirlemiştir (Li, 2018; Soykan, Gardner ve Edwards, 2019; Youssef Morgan ve Luthans, 2015). Bu araştırmaların ortak teması; örgüt çalışanlarının olumlu davranışlar sergilemelerinde kilit bir öğe olan psikolojik sermayenin aynı zamanda psikolojik iyi oluşu artırması ve buna bağlı olarak çalışanların daha yüksek performans sergilemeleridir. Bu verilerden hareketle; örgütsel performansın artırılmasında bireysel kaynakların geliştirilmesini vurgulayan psikolojik sermaye, verimli iş gücü üzerinde etkisi kanıtlanmış psikolojik iyi oluşun korunması ve arttırılmasında önemli bir unsurdur. Hem politikanın belirlediği hedeflere, hem de çalıştığı okulun ve öğrencilerin ihtiyaçlarına cevap vermeye çalışan okul danışmanlarının olumsuz örgüt davranışları sergilemelerinin önüne geçmek iyimserlik, umut, öz-yeterlik ve psikolojik dayanıklılıklarını dolayısıyla da psikolojik iyi oluşlarını geliştirmelerine bağlıdır.

\subsection{Psikolojik İyi Oluş ve Başa Çıkma Tarzları}

Okullarda görev yapan danışmanların pek çok sorunla karşılaştığını çalışmamızın başında da ifade etmiştik. İdareci ve diğer öğretmenlerle iletişim sorunları, velilerle irtibat kuramamak ve işbirliği yapamamak, yoğun iş yükünün altında ezilmek ve yüksek riskli öğrenci davranışlarıyla karşı karşıya kalmak bu sorunlar arasında yer almaktadır. Danışmanların çalışmalarını sürdürmeleri, karşılaştıkları sorunlarla ve olumsuz duygularıyla başa çıkabilmelerine bağlıdır. Başa çıkma, sorunlara yönelik bilinçli ve kasıtlı eylemleri içerir (Lazarus ve Folkman, 1984). Çeşitli stres kaynaklarıyla başa çıkmak için pek çok tarz olduğu ifade edilse de en yaygın kullanılanlar "problem odaklı ve duygu odaklı" başa çıkmadır (Baker ve Berenbaum, 2007; Dysvik, Natvig, Eikeland ve Lindstrom, 2005). Problem odakl1 başa çıkma; stresörleri değiştirmek veya varlıklarını sona erdirmek için gösterilen aktif çabayı ifade ederken, stresli olayların duygusal sonuçlarını azaltmaya yönelik tüm düzenleyici çabalar duygu odaklı başa çıkma olarak tanımlanır (Folkman ve Moskowitz, 2007). Stres kaynaklarına karş1 kendine güvenli olmak, iyimser yaklaşmak veya sosyal desteğe başvurmak problem odaklı yaklaşım çerçevesinde, çaresiz ve boyun eğici yaklaşmak ise duygu odaklı başa çıkma kapsamında değerlendirilir (Şahin ve Durak, 1995). Kendine güvenli yaklaşım stresörlere yaklaşımda karar verme ve problem çözme gibi becerileri kullanmayı içerirken, iyimser bakış açısı sorunların çözülebilirliğine yönelik olumlu bir inancı simgeler. Sosyal destek arama ise, bireyin problemle karşı karşıya kaldığında aile ve arkadaş gibi kaynakların desteğine başvurmasını ifade eder. Bu aktif çabaların tam tersi olarak ise boyun eğici yaklaşım sorunların çözümüne ilişkin umutsuz bir inancı ve çaba göstermemeyi, çaresiz yaklaşım etkili başa çıkma yollarının bilinmemesine bağlı olarak harekete geçememeyi temsil eder. Önceki bulgular, stres kaynaklarına problem odaklı yaklaşmanın doğrudan psikolojik iyi oluşa katkıda bulunduğunu, duygu odaklı yaklaşmanın ise psikolojik sıkıntının güçlü bir göstergesi olduğunu ifade etmektedir (Gustems Carnicer ve Calderón, 2013; Mayordomo Rodríguez, Meléndez Moral, Viguer Segui ve Sales Galán, 2015). Okul danışmanları olumlu baş etme kaynaklarını devreye sokarak örgütsel problemlerini yönetebilirler. Bu durumun aksi söz konusu olduğunda, yani danışmanlar problemleriyle etkili bir şekilde başa çıkamadıklarında çeşitli araştırmaların da desteklediği şekilde tükenmişlik, iş stresi ve performans düşüklüğü yaşayabilirler (Shorosh ve Berkovich, 2020; Tummers, 2016). Bu kavramların psikolojik iyilik hali üzerindeki olumsuz etkileri değerlendirildiğinde, stres kaynaklarıyla nasıl başa çıkıldığının iyi oluş üzerinde önemli bir belirleyici olduğundan söz edilebilir. Bu bilgi alanda yapılan araştırmalar tarafından da desteklenmektedir (Gustems Carnier ve Calderón, 2013; Stapleton, Garby ve Sabot, 2020). Psikolojik iyi oluş üzerinde önemli bir belirleyen konumunda olan başa çıkma tarzları hangi tarzın kullanıldığına bağlı olarak iyi oluşa olumlu veya olumsuz katkı sunabilmektedir. Bu bağlamda; çalışma şartları nedeniyle sıklıkla stres verici durumlarla karşı karşıya kalan 
danışmanların kullandıkları başa çıkma tarzlarının ve bunların etkisiyle şekillenen psikolojik iyi oluşlarının sundukları hizmetin kalitesini etkileyeceği aktarılabilir. Bir başka deyişle, yaşam stresörlerini aktif yönetebilen uzmanların yüksek iyilik hâlinde olmalarına bağlı olarak rehberlik ve psikolojik danışma hizmetlerinde daha etkili performans gösterdikleri öngörülmektedir.

\subsection{Mevcut Çalışma}

Rehberlik ve psikolojik danışma programını yönetmenin yanında, hem entelektüel hem deduygusal hem de ahlaki açıdan dengeli bireyler yetiştirme gayesi içinde olan okul danışmanlarının psikolojik iyi oluşlarını anlamak için yeni çalışmalara ihtiyaç vardır. Özellikle öğrencilerin psikolojik sağlıklarından sorumlu olan danışmanların kendilerini mesleki olarak geliştirmelerinin yanında kişisel gelişimlerini de desteklemeleri gerekir. Bu sayede okul danışmanları faaliyetlerini daha etkili şekilde sürdürebilir ve diğerlerinin psikolojik sorunlarına yardım etme kapasitelerini artırabilirler. Bu çalışmanın amacı, okul psikolojik danışmanlarının psikolojik iyi oluşları üzerinde psikolojik sermaye ve başa çıkma tarzlarının rolünü belirlemektir. Bu amaçla bağlantılı olarak çalışmamızda aşağıdaki sorulara cevap aranmıştır:

1. Okul danışmanlarının psikolojik iyi oluşları, psikolojik sermaye düzeyleri ve başa çıkma tarzları arasında anlamlı ilişkiler var mıdır?

2. Okul danışmanlarının psikolojik sermaye düzeyleri psikolojik iyi oluşlarını anlamlı düzeyde yordamakta mıdır?

3. Okul danışmanlarının başa çıkma tarzları psikolojik iyi oluşlarını anlamlı düzeyde yordamakta midir?

\section{YÖNTEM}

Araştırmanın ele alınan bu bölümünde; araştırma modeli, prosedür ve etik onay, araştırmanın çalışma grubu, kullanılan veri toplama araçları, elde edilen verilerin düzenlenmesi ve analizine dair içerikler yer almaktadır.

\subsection{Araştırma Modeli}

Okul psikolojik danışmanlarının psikolojik iyi oluşları üzerinde psikolojik sermaye düzeyleri ve başa çıkma tarzlarının rolünün ortaya koyulmasını amaçlayan bu çalışma ilişkisel modele uygun olarak tasarlanmıştır. İlişkisel model, en az iki değişken arasındaki ilişkinin belirlenmesinde kullanılır (Fraenkel, Wallen ve Hyun, 2012). Bu tür araştırmaların temelini iki değişken arasındaki ilişkinin üçüncü bir değişken tarafından kontrol ediliyor olabileceği ve insan davranışlarındaki farklılıkları kavramsal değişkenlerin farklı yollarını açıklığa kavuşturacak şekilde açıklık getirme düşüncesi oluşturmaktadır (Baron ve Kenny, 1986).

\subsection{Prosedür ve Etik Onay}

Araştırmaya başlamadan önce Trabzon Üniversitesi’nden 81614018-000-E.565 sayılı etik kurul izni alınmıştır. Çalışmanın verileri 2020-2021 eğitim-öğretim yılı güz döneminde toplanmıştır. Ölçekler okul psikolojik danışmanlarına çevrim içi olarak gönderilmiştir. Araştırmaya gönüllü olarak katılım gösteren danışmanların doldurdukları formlar değerlendirmeye alınmıştır.

\section{3. Çalışma Grubu}

$\mathrm{Bu}$ araştırmada çalışma grubunu 2020-2021 akademik y1lında Trabzon ilindeki kurumlarda çalışmakta olan 157 kadın (\% 73.4), 57 erkek (\% 26.6) toplam 214 psikolojik danışman oluşturmaktadır. Yaşları 24 ile 54 arasında değişen katılımcıların yaş ortalaması 35.87'dir. Çalışma grubuna ilişkin ayrıntılı bilgi Tablo 1'de verilmiştir. 
Tablo 1. Katılımcıların Demografik Özellikleri

\begin{tabular}{llll}
\hline Değişkenler & Grup & $\mathrm{N}$ & $\%$ \\
\hline \multirow{2}{*}{ Cinsiyet } & Kadın & 157 & 73.4 \\
& Erkek & 57 & 26.6 \\
\hline \multirow{2}{*}{ Eğitim Düzeyi } & Lisans & 166 & 77.6 \\
& Yüksek Lisans & 42 & 19.6 \\
& Doktora & 6 & 2.8 \\
\hline \multirow{2}{*}{ Hizmet Y1lı } & $1-5$ yıl & 35 & 16.4 \\
& $6-10$ yıl & 66 & 30.8 \\
& $11-15$ yıl & 45 & 21 \\
& $16-20$ yıl & 30 & 14 \\
& 20 yıl ve sonrası & 38 & 17.8 \\
\hline \multirow{2}{*}{ Görev Yapılan Kurum } & İlkokul & 35 & 16.4 \\
& Ortaokul & 82 & 38.3 \\
& Lise & 60 & 28 \\
& RAM & 28 & 13.1 \\
& Diğer & 9 & 4.2 \\
\hline
\end{tabular}

RAM: Rehberlik Araştırma Merkezi.

Katılımcıların eğitim düzeylerine bakıldığında 166'sının (\% 77.6) lisans, 42'sinin (\% 19.6) yüksek lisans ve 6 'sının (\% 2.8) doktora eğitimini tamamladığı belirlenmiş̧tir. Araştırma grubu farklı mesleki deneyimlere sahiptir. 35'i (\%16.4) 1 ile 5 y1l, 66's1 (\%30.8) 6 ile 10 y1l, 45'i (\%21) 11 ile 15 yıl, 30’u (\%14) 16 ile 20 yıl arasında ve 38'i (\%17.8) 21 yil ve üzerinde görev yapmıştır. Araştırma grubunu oluşturan danışmanların görev yaptıkları kurum türleri de birbirinden farklılık göstermektedir. Danışmanların 35'i (\%16.4) ilkokulda, 82'si (\%38.8) ortaokulda, 60'1 (\%28) lisede, 28'i (\%13.1) Rehberlik Araştırma Merkezi'nde (RAM) ve 9'u (\%4.2) diğer kurumlarda görev yapmaktadır.

\subsection{Veri Toplama Araçları}

2.4.1. Demografik bilgi formu. Araştırmacıların hazırladığı form; katılımcıların cinsiyeti, eğitim düzeyi, hizmet yılı ve görev yapmakta oldukları kurum türünü belirlemeye yönelik sorular içermektedir.

2.4.2. Warwick-Edinburgh mental iyi oluş ölçeği. Alt boyutu bulunmayan ve 14 maddeden oluşan orijinal ölçeği Tennant ve diğerleri (2007) geliştirmiştir. Ölçeğe dair geçerlilik ve güvenirlik çalışmaları 16 yaş ve üzeri bireylerle gerçekleştirilmiş olup Cronbach Alfa katsayısı 0.89 olarak saptanmıştır. Ölçeğin Keldal (2015) tarafından gerçekleştirilen Türkçeye uyarlama çalışmasında iç tutarlık katsayısı $(\alpha)$ 0.92'dir. Gerçekleştirilen bu araştırmada araştırma grubundan toplanan verilere ilişkin iç tutarlık katsayısı ise $(\alpha) 0.89$ bulunmuştur.

2.4.3. Örgütsel psikolojik sermaye ölçeği. 6'lı likert tipinde hazırlanan ve 24 maddeden oluşan bu ölçek Luthans ve diğerleri (2007) tarafından geliştirilmiştir. İyimserlik, psikolojik dayanıklılık, umut ve öz yeterlik olmak üzere 4 alt boyutu olan ölçeğin Türkçeye uyarlama çalışmasını Çetin ve Basım (2012) gerçekleştirmiştir. Uyarlama çalışmasında ölçeğin toplamına ilişskin iç tutarlık katsayısı $(\alpha) 0.91$ olarak belirtilirken, alt boyutlarına dair iç tutarlık katsayıları 0.67 ile 0.85 arasında değişmektedir. Bu çalışmada elde edilen verilere ilişkin ölçme aracına ait katsayısı $(\alpha) 0.90$ olarak saptanmıştır. Alt boyutlarına ilişkin iç tutarlık katsayıları ise "iyimserlik" için $(\alpha)$ 0.54, "psikolojik dayanıkl1lık" için $(\alpha)$ 0.75, "umut" için $(\alpha) 0.71$ ve "öz yeterlik" için $(\alpha) 0.89$ olarak belirlenmiştir.

2.4.4. Stresle başa çıkma tarzları ölçeği. 4'lü Likert tipinde hazırlanmış ölçek Folkman ve Lazarus (1980) tarafından geliştirilmiştir. Ölçeğin Türkçe formunu Şahin ve Durak (1995) uyarlamıştır. Ölçeğin; problem ve duygu odaklı olacak şekilde iki temel boyutu vardır. Ölçeğin 
bütününe yönelik güvenirlik katsayısı 0.68 olarak belirlenmiştir. Bu çalışma kapsamında ölçeğin bütününe ilişkin iç tutarlık katsayısı $(\alpha) 0.71$ olarak hesaplanırken, alt boyutlara ilişkin iç tutarlık katsayıları ise "problem odaklı başa çıkma tarzı" için $(\alpha) 0.80$, "duygu odaklı başa çıkma" için $(\alpha) 0.73$ hesaplanmıştır. Alt boyutlara ilişkin iç tutarlık katsayıları ise "kendine güvenli yaklaşım" boyutu için $(\alpha)$ 0.87, "iyimser yaklaşım" boyutu için $(\alpha) 0.60$, "sosyal destek arama" boyutu için $(\alpha) 0.61$, "çaresiz yaklaşım" boyutu için $(\alpha) 0.54$ ve "boyun eğici yaklaşım" boyutu için $(\alpha) 0.59$ olarak hesaplanmıştır.

\subsection{Verilerin Düzenlenmesi ve Analizi}

Araştırma sürecinde elde edilen verileri istatistiki anlamda analize tabi tutmadan önce bazı düzenlemelerin yapılması gerekmektedir (Field, 2013). Bu bağlamda kayıp değer, uç değer aynı zamanda normal dağılım analizleri gerçekleştirilmiştir. Toplanan veriler içerisinde kayıp değerin olmadığı sonucuna ulaşılmış ve bir sonraki basamak olan uç değer analizine geçilmiştir. 17 kişi uç değer nedeniyle veri setinden çıkarılmıştır. Geriye kalan verilerin normallik varsayımını sağlayıp sağlamadığını belirlemek için çarpıklık ve basıklık değerlerine bakılmıştır. Tablo 2'de görüldüğü üzere değerlerin -1.5 ve +1.5 aralığında olması normal dağılım varsayımını sağladığını göstermektedir (Tabachnick ve Fidell, 2013).

Tablo 2. Değişkenlere İlişskin Çarpıklık ve Basıklık Katsayıları

\begin{tabular}{|l|c|l|c|c|c|c|c|r|}
\hline \multirow{2}{*}{ Değişkenler } & \multirow{2}{*}{ Min. } & \multirow{2}{*}{ Max. } & \multirow{2}{*}{ Mean } & \multirow{2}{*}{ SD } & \multicolumn{2}{|c|}{ Çarpılık } & \multicolumn{2}{|c|}{ Basıklı } \\
\cline { 6 - 9 } & & & & & Değer & Hata & Değer & Hata \\
\hline PİO & 35 & 70 & 54.6 & 6.25 & -.275 & .166 & .512 & .331 \\
\hline İyimserlik & 18 & 36 & 27.22 & 3.36 & -.117 & .166 & .095 & .331 \\
\hline PD & 20 & 36 & 28.62 & 3.25 & -.170 & .166 & -.051 & .331 \\
\hline Umut & 18 & 36 & 28.57 & 3.22 & -.160 & .166 & -.217 & .331 \\
\hline Öz yeterlik & 14 & 36 & 29.55 & 3.74 & -.935 & .166 & 1.376 & .331 \\
\hline KGY & 14 & 28 & 22.38 & 3.26 & .002 & .166 & -.499 & .331 \\
\hline IY & 9 & 19 & 14.23 & 2.14 & -.112 & .166 & -.200 & .331 \\
\hline SDA & 6 & 14 & 10.43 & 1.64 & -.011 & .166 & -.077 & .331 \\
\hline ÇY & 10 & 24 & 16.84 & 2.86 & .186 & .166 & -.290 & .331 \\
\hline BEY & 6 & 17 & 10.63 & 2.39 & .129 & .166 & -.361 & .331 \\
\hline
\end{tabular}

PİO: Psikolojik İyi Oluş; PD: Psikolojik Dayanıklılık; KGY: Kendine Güvenli Yaklaşım; İY: İyimser Yaklaşım; SDA: Sosyal Destek Arama; ÇY: Çaresiz Yaklaşım; BEY: Boyun Eğici Yaklaşım.

Okul psikolojik danışmanlarının psikolojik sermaye düzeyleri ve başa çıkma tarzlarının psikolojik iyi oluşları üzerindeki etkisini belirlemek amacıyla yürütülen araştırmada elde edilen verilerin çözümlenmesi iki aşamalı olarak gerçekleştirilmiştir. İlk olarak okul psikolojik danışmanlarının psikolojik iyi oluşları, psikolojik sermayeleri ve başa çıkma tarzları arasındaki ilişkiler Pearson momentler çarpımı korelasyon tekniği kullanılarak analiz edilmiştir. İkinci olarak psikolojik sermaye ile başa çıkma tarzlarının psikolojik iyi oluşu ne ölçüde yordadığ 1 Hiyerarşik Regresyon analizi ile belirlenmiştir. Regresyon analizi öncesinde bir takım ön koşulların sağlanıp sağlanmadığı test edilmiştir. Öncelikli olarak değişkenlerin ikili ilişkileri incelenmiş ayrıca çoklu eş doğrusallığın kontrolü sağlanmıştır. Değişkenler arasındaki korelasyon değerlerinin 0.80 'den küçük ve Durbin Watson değerinin de (1.78) normal sınırlarda olduğu belirlenmiştir (Field, 2013). Ardından tolerans değeri (1-R2) ve varyans büyütme faktörüne (VIF) bakılmıştır. Tüm tolerans değerlerinin .20 ölçütünden daha büyük (.26 ile .67 arasında) olması ve en büyük VIF değerinin (3.14) 4'den daha düşük olmasına bağlı olarak çoklu bağlantı problemi olmadığına karar verilmiştir (Hair, Black, Babin ve Anderson, 2010). Çalışmada psikolojik sermaye ile başa çıkma tarzları bağımsız, psikolojik iyi oluş ise bağımlı değişken olarak değerlendirilmiştir. Araştırmanın birinci ve ikinci sırasındaki işlemlerin gerçekleşmesinde SPSS 22.0 paket programından yararlanılmıştır. 


\section{BULGULAR}

Regresyon analizi öncesinde okul psikolojik danışmanlarının psikolojik iyi oluşları, psikolojik sermayeleri ve başa çıkma tarzları arasındaki ilişkilerin değerlendirilebilmesi için Pearson momentler çarpımı korelasyon analizi gerçekleştirilmiş, bulgular Tablo 3'te özetlenmiştir.

Tablo 3. Psikolojik İyi Oluş, Psikolojik Sermaye ve Başa Çıkma Tarzları Arasındaki İlişkiler

\begin{tabular}{lllllllllll}
\hline Değişkenler & 1 & 2 & 3 & 4 & 5 & 6 & 7 & 8 & 9 & 10 \\
\hline 1. Pं் & 1 & & & & & & & & & \\
2. İyimserlik & $.53^{* *}$ & 1 & & & & & & & & \\
3. PD & $.53^{* *}$ & $.57^{* *}$ & 1 & & & & & & & \\
4. Umut & $.63^{* *}$ & $.56^{* *}$ & $.69^{* *}$ & 1 & & & & & & \\
5. Öz yeterlik & $.61^{* *}$ & $.52^{* *}$ & $.73^{* *}$ & $.77^{* *}$ & 1 & & & & & \\
6. KGY & $.53^{* *}$ & $.48^{* *}$ & $.60^{* *}$ & $.62^{* *}$ & $.57^{* *}$ & 1 & & & & \\
7. IY & $.28^{* *}$ & $.44^{* *}$ & $.50^{* *}$ & $.43^{* *}$ & $-.37^{* *}$ & $.66^{* *}$ & 1 & & & \\
8. SDA & -.001 & $.12^{*}$ & .004 & -.02 & -.02 & .04 & .00 & 1 & & \\
9. ÇY & $-.29^{* *}$ & $-.21^{* *}$ & $-.29^{* *}$ & $-.30^{* *}$ & $-.35^{* *}$ & $-.26^{* *}$ & $-.20^{*}$ & $.33^{* *}$ & 1 & \\
10. BEY & $-.22^{* *}$ & -.04 & $-.19^{*}$ & $-.18^{*}$ & $-.15^{*}$ & -.11 & .06 & $.36^{* *}$ & $.49^{* *}$ & 1 \\
\hline
\end{tabular}

**p<.001; * p <.05 PİO: Psikolojik İyi Oluş; PD: Psikolojik Dayanıklılık; KGY: Kendine Güvenli Yaklaşım; IY: İyimser Yaklaşım; SDA: Sosyal Destek Arama; ÇY: Çaresiz Yaklaşım; BEY: Boyun Eğici Yaklaşım.

Değişkenler arası korelasyonlara ilişkin bulgular incelendiğinde psikolojik iyi oluş ile psikolojik sermayenin alt boyutlarından iyimserlik $(\mathrm{r}=.53, \mathrm{p}<.001)$, psikolojik dayanıkl1lik $(\mathrm{r}=$ $.53, \mathrm{p}<.001)$, umut $(\mathrm{r}=.63 . \mathrm{p}<.001)$, öz yeterlik $(\mathrm{r}=.61, \mathrm{p}<.001)$ ve problem odaklı tarzın alt boyutlarından kendine güvenli yaklaşım $(\mathrm{r}=.53, \mathrm{p}<.001)$ ve iyimser yaklaşım $(\mathrm{r}=.28, \mathrm{p}<.001)$ arasında pozitif yönde anlamlı ilişkiler olduğu belirlenmiştir. Psikolojik iyi oluş ile duygu odaklı tarza ilişkin alt boyutlar olan çaresiz yaklaşım $(r=-.29, p<.001)$ ve boyun eğici yaklaşım $(r=-$ $.22, \mathrm{p}<.001$ ) arasında ise negatif yönde anlamlı bir ilişki saptanmıştır.

Değişkenler arasındaki ilişkiler belirlendikten sonra psikolojik iyi oluş bağımlı değişken olarak ele alınmış ve iki aşamalı hiyerarşik regresyon analizine tabi tutulmasına karar verilmiştir. İki aşamalı modelin ilk aşaması psikolojik sermaye alt boyutlarını, ikinci aşaması ise problem ve duygu odaklı tarzlara ait alt boyutları içermektedir. Hiyerarşik regresyon analizi sonuçları Tablo 4'de sunulmuştur.

Tablo 4. Psikolojik İyi Oluşa İlişkin Hiyerarşik Regresyon Analizi

\begin{tabular}{|c|c|c|c|c|c|c|c|c|c|c|}
\hline & & $\mathrm{R}$ & $\mathrm{R}^{2}$ & $\Delta \mathrm{R}^{2}$ & $f^{2}$ & $\mathrm{~F}$ & $d f$ & B & $\beta$ & $t$ \\
\hline \multirow{6}{*}{1} & Constant & & & & & & & 13.50 & & $4.26^{* *}$ \\
\hline & İyimserlik & & & & & & & .41 & .22 & $3.43^{* *}$ \\
\hline & $\mathrm{PD}$ & & & & & & & .00 & .00 & .02 \\
\hline & Umut & & & & & & & .62 & .32 & $3.77 * *$ \\
\hline & $\begin{array}{l}\text { Öz } \\
\text { Yeterlik }\end{array}$ & & & & & & & .41 & .25 & $2.84 *$ \\
\hline & & .68 & .47 & .46 & .89 & $45.937 *$ & $4 / 209$ & & & \\
\hline
\end{tabular}


Tablo 4. (devamı)

\begin{tabular}{|c|c|c|c|c|c|c|c|c|c|c|}
\hline & & $\mathrm{R}$ & $\mathrm{R} 2$ & $\Delta \mathrm{R} 2$ & $\mathrm{f} 2$ & $\mathrm{~F}$ & $\mathrm{df}$ & $\mathrm{B}$ & $\beta$ & $\mathrm{t}$ \\
\hline \multirow{11}{*}{2} & Constant & & & & & & & 19.12 & & $4.31 * *$ \\
\hline & İyimserlik & & & & & & & .44 & .24 & $3.64 * *$ \\
\hline & $\mathrm{PD}$ & & & & & & & -.05 & -.03 & -.31 \\
\hline & Umut & & & & & & & .49 & .25 & $2.93^{*}$ \\
\hline & $\begin{array}{l}\text { Öz } \\
\text { Yeterlik }\end{array}$ & & & & & & & .35 & .21 & $2.37 *$ \\
\hline & KGY & & & & & & & .45 & .23 & $3.01 *$ \\
\hline & İY & & & & & & & -.43 & -.15 & $-2.10^{*}$ \\
\hline & SDA & & & & & & & .04 & .01 & .18 \\
\hline & ÇY & & & & & & & -.05 & -.02 & -.36 \\
\hline & BEY & & & & & & & -.26 & -.10 & -1.63 \\
\hline & & .71 & .51 & .49 & 1.04 & $23.245^{*}$ & $5 / 204$ & & & \\
\hline
\end{tabular}

$\mathrm{N}=214 ; * * \mathrm{p}<.001 ; * \mathrm{p}<.05 ; \mathrm{f}^{2}>.35$, büyük etki (Cohen,1988); PD: Psikolojik Dayanıkl11ık; KGY: Kendine Güvenli Yaklaşım; IY: İyimser Yaklaşım; SDA: Sosyal Destek Arama; ÇY: Çaresiz Yaklaşım; BEY: Boyun Eğici Yaklaşım.

İlk aşamada psikolojik sermayenin alt boyutlarından iyimserlik $(\beta=0.22, p<0.05)$, umut $(\beta=0.32, p<0.001)$ ve öz yeterliğin $(\beta=0.25, p<0.05)$ modele katkısının anlamlı olduğu belirlenmiştir. İkinci aşamada problem ve duygu odaklı tarzlar modele eklenmiş ve problem odaklı tarzın alt boyutlarından kendine güvenli yaklaşım $(\beta=.23, \mathrm{p}<0.05)$ ve iyimser yaklaşımın $(\beta=-.15, \mathrm{p}<0.05)$ modele katkısının istatistiksel olarak anlamlı olduğu saptanmıştır. Ayrıca psikolojik dayanıklılık $(\beta=.00, \mathrm{p}>0.05)$, sosyal destek arama $(\beta=.01, \mathrm{p}>0.05)$, çaresiz yaklaşım $(\beta=-.02, p>0.05)$ ve boyun eğici yaklaşımın $(\beta=-.10, p>0.05)$ modele katkısının anlamsız olduğu belirlenmiş̧tir. Sonuçlara göre iyimserlik, umut ve öz yeterlik modelin \%.46'sını açıklamakta ve modele önemli bir katkı sağlamaktadır. Güvenli yaklaşım ile iyimser yaklaşımın modele sunduğu özgün varyans ise \%.3'tür .

\section{TARTIŞMA, SONUÇ VE ÖNERILER}

Gerçekleştirilen bu çalışmada okul psikolojik danışmanlarının psikolojik sermaye düzeyleri ile problem ve duygu odaklı tarzların psikolojik iyi oluşları üzerindeki etkisi değerlendirilmiştir. Yapılan analizler sonucunda psikolojik sermayenin alt boyutlarından "iyimserlik", "umut" ve "öz yeterliğin" modele önemli düzeyde pozitif yönde katk1 sağladığı bulunurken diğer bir alt boyut olan psikolojik dayanıklılı̆̆ın modele katkısının anlamsız olduğu belirlenmiştir. Modele ikinci aşamada dâhil edilen problem odaklı tarzın alt boyutlarından kendine güvenli yaklaşımın pozitif yönde, iyimser yaklaşım ise negatif yönde modele düşük düzeyde katkı sunduğu görülürken, sosyal destek aramanın modele katkısının anlamsız olduğu saptanmıştır. Son olarak duygu odaklı tarzın alt boyutları olan çaresiz yaklaşım ile boyun eğici yaklaşımın da modele katkısının istatistiki olarak anlamsız olduğu bulunmuştur.

Araştırmanın sonucuna göre psikolojik sermayenin alt boyutlarından "iyimserlik" okul psikolojik danışmanlarının iyi oluşlarına pozitif yönde anlamlı bir katkı sunmaktadır. Araştırmanın bu sonucu alanyazındaki birçok çalışmayla (Avey, Luthans, Smith ve Palmer, 2010; Değirmenci, 2019; Diener ve diğerleri, 2010; Göçen, 2019; Satıc1 ve Deniz, 2017) benzerlik göstermektedir. Psikolojik sermaye kapsamındaki iyimserlik; sorunlara karşı aktif bir tutum sergileyerek daha çok çalışma motivasyonuna sahip, belirlenen hedefleri gerçekleştirmekte istekli, zamanında müdahaleci bir eğilimi ifade etmektedir (Youssef Morgan ve Luthans, 2007; Luthans ve diğerleri, 2007). Okul psikolojik danışmanları iş yaşantılarında meslek tanımlarının henüz tam olarak bir çerçevesinin çizilmemesi, okul yöneticilerinin ön yargılı tutumları, mesleki etik kurallarıyla ters düşen iş ve işlemlerde görevlendirilmeleri, okul 
ortamında yeterli işbirliğini sağlayamamaları, öğrencilerde istendik ve kalıcı davranış değişikliğinin zorluğu (Arslan, Karataş ve Dostuoğlu, 2019; Çokamay, Kapçı ve Sever, 2017; Monteiro Leitner ve diğerleri, 2006; Parmaksız ve Gök, 2018; Perusse ve diğerleri, 2004) gibi birçok sorunla karşılaşmaktadırlar. Okul psikolojik danışmanlarının bu sorun alanları ile baş etmede kişiyi motive eden, sorunları ve kişisel hatalarını yetersizlik olarak görmek yerine geçici ve değiştirilebilir olarak algılamasını sağlayan, gerçekçi ve hedeflere ulaşma konusunda istekli kılan iyimser bir tutumu benimsemelerinin psikolojik iyi oluşlarını olumlu yönde etkilemesinin doğal bir sonuç olduğu düşünülmektedir.

Alanyazında umudun iyi oluş üzerinde pozitif etkisinin olduğunu ortaya koyan pek çok çalışma (Chang, 2003; Demirci, 2020; Demirtaş, Baytemir ve Güllü, 2018; Shorey, Little, Snyder, Kluck ve Robitschek, 2007; Yalçın ve Malkoç, 2015) bu araştırmada elde edilen, umudun psikolojik iyi oluşu pozitif yönde yordadığı bulgusunu desteklemektedir. Okul psikolojik danışmanlarının sundukları yardım hizmeti planlı bir protokolü takip eden, danışman ve danışanın belirlenen amaçlar doğrultusunda, değişimi gerçekleştirmek için hedeflenen amaçlara giden farklı yolları belirledikleri ve değişim için motive olmayı gerektiren profesyonel bir süreçtir (Corey, 2008). Amaca götüren yolları planlama ve kendini motive etme bileşenlerinden oluşan umut (Snyder ve Cheavens, 2000; Snyder, Feldman, Shorey ve Rand, 2002), sunulan psikolojik yardım hizmetinin nitelikli olmasına katkı sağlayacak ve psikolojik danışmanların iş doyumlarını artırarak iyi oluşlarını arttıracaktır. Fiziksel ve ruhsal sağlık üzerinde etkili olan umut (Frankham, Richardson ve Maguire, 2020; Long ve diğerleri, 2020), insan yaşamının kaynağı olarak (Kylma, 2005) görülmesinin yanı sıra psikolojik iyi oluşu etkileyen tükenmişlik, olumsuz otomatik düşünce, travma, depresyon ve anksiyeteyi (Arnau, Rosen, Finch, Rhudy ve Fortunato, 2007; Fletcher, 2018; Kumcağız, Şahin, Alakuş ve Akbaş, 2017; Passmore, Hemming, McIntosh ve Hellman, 2020; Wong ve Lim, 2009) azaltarak, iyi oluşa katkıda bulunan bir iyileştirme kuvveti (Holdcraft ve Williamson, 1991) olarak düşünülmektedir. Ayrıca yüksek umut düzeyine sahip olmak, işe yönelik anlam, işten ve yaşamdan alınan doyum, iyi bir yaşam beklentisi, geleceğe yönelik yaşam amaçları belirleme, yapılan işte kararlılık ve planlanan işi tamamlama (Long ve diğerleri, 2020, Passmore ve diğerleri, 2020; Snyder ve diğerleri, 2002; Vidwans ve Raghvendra, 2016) üzerinde de etkilidir. Umut ile ilgili tüm bu bilgiler, araştırmanın sonuçlarından biri olan, umudun psikolojik iyi oluşu pozitif yönde yordamasının nedenlerini açıklar niteliktedir.

Araştırmanın bir diğer sonucuna göre okul psikolojik danışmanlarının öz yeterlikleri psikolojik iyi oluşlarını pozitif yönde yordamaktadır. Yapılan alanyazın taramasında araştırmanın bu sonucunu destekleyen çalışmalar (De Caroli ve Sagone, 2014; Göçen, 2019; K1lınç, 2017) olduğu görülmüştür. Öz yeterlik kişinin bir alanda sergileyeceği performansa yönelik ihtiyaç duyduğu yeteneklerine olan inancıdır (Bandura, 1977). Psikolojik danışmanların sunduğu profesyonel yardımın etkili olması danışman ile danışan arasında kurulacak terapötik ilişkinin niteliğine bağlıdır. Terapötik ilişkinin sağlıklı olması ise danışmanın etkili psikolojik danışman özelliklerine sahip olması ile mümkündür. Bu bağlamda danışmanların gerekli kişilik özelliklerini taşımasının yanı sıra psikolojik danışmanlık ile ilişkili teorik bilgi, beceri ve yetenek konusunda yetkin olmaları gerekmektedir (Hackney ve Cormier, 2008). Psikolojik danışmanın yetkin olmaması etik çatışma yaşamasına neden olurken, mesleğin olmazsa olmazı terapötik ilişkiyi, güven ve sadakat gibi birçok ilkeyi sarsarak mesleğin sağlıklı şekilde yürütülmesini engellemektedir (Arslan ve diğerleri, 2019; Çokamay ve diğerleri, 2017). Bu durumun pozitif bir oluşum olan (Ryff ve Keyes, 1995) psikolojik iyi oluş üzerinde etkili olması kaçınılmazdır. Buradan hareketle araştırmanın bu bulgusu, alanda yetkin olan okul danışmanlarının mesleki çalışmalarını daha sağlıklı ve etkili yürütmelerine bağlı olarak daha az etik çatışma yaşacakları ve psikolojik iyilik hâllerinin yüksek düzeyde olacağı şeklinde açıklanabilir.

Araştırmada psikolojik dayanıklılık ile psikolojik iyi oluş arasındaki ilişkinin anlamlı olmasına rağmen psikolojik dayanıklılığın okul danışmanlarının iyi oluşları üzerindeki etkisinin 
anlamlı olmadığı belirlenmiştir. $\mathrm{Bu}$ sonuç alanyazındaki bazı çalışmalar tarafindan desteklenmemesine (Değirmenci, 2019; Cohn, Fredrickson, Brown, Mikels ve Conway, 2009; Kaba ve Keklik, 2016) karşın, sınırlı sayıda da olsa araştırmanın bu bulgusunu destekleyen çalışmalar mevcuttur ve araştırmacılar çalışmalarındaki bu durumu çalıştıkları örneklem büyüklüğünün yetersiz olmasına bağlı olarak açıklamaktadırlar (Duman, Göksu, Köroğlu ve Talay, 2020; Göçen, 2019). Benzer şekilde bu araştırmada da örneklem büyüklüğünün ortaya çıkan bu sonuç üzerinde etkili olabileceği değerlendirilebilir. Öte yandan psikolojik dayanıklılık; bireyin yaşadığı zorlu yaşam deneyimleri ile baş edebilmesi, kendini yeniden toparlayabilme kapasitesidir. Geliştirilebilen bir yapısı olan psikolojik dayanıklılığının yüksek olması bireyin üstesinden geldiği sorun alanları ve yeniden toparlayabilmesi ile doğru orantılıdır (Luthans, Vogelgesang ve Lester, 2006). Psikolojik danışmanlar umutsuz, ruhsal açıdan çökkün ve ağır travmatik öyküleri bulunan bireylerle sık karşılaşmaktadır (Culver, McKinney ve Paradise, 2011). Bu durumun psikolojik danışmanların psikolojik dayanıklılıklarını geliştiren kendi yaşamlarında başa çıktıkları sorun alanlarını psikolojik iyi oluşlarını etkileyecek düzeyde görmemelerine neden olarak, araştırmada böyle bir sonucu ortaya çıkardığg düşünülebilir.

Bireylerin stres kaynaklarına yönelik kullandıkları başa etme stillerinin psikolojik iyi oluş üzerindeki etkilerine bakıldığında; problem odaklı baş etmenin hem kendine güvenli hem de iyimser yaklaşım alt boyutları psikolojik danışmanların iyi oluşları üzerinde düşük düzeyde anlamlı etkiye sahipken, duygu odaklı başa etmenin alt boyutlarından çaresiz ve boyun eğici yaklaşımın etkisi anlamlı değildir. Alanyazındaki birçok çalışma psikolojik iyi oluş üzerinde problem odaklı baş etmenin anlamlı etkisini desteklemektedir (Malkoç ve Yalçın; 2015; Mayordomo Rodriguez ve diğerleri, 2015; Sagone ve Caroli, 2014). Okul psikolojik danışmanları yaptıkları iş ve çalışma ortamlarından kaynaklı yaşadıkları sorunlar nedeniyle, sık s1k strese maruz kalmaktadırlar (Arslan ve diğerleri, 2019; Çokamay ve diğerleri, 2017). Yapılan çalışmalar artan stres düzeyinin psikolojik iyi oluşu olumsuz olarak etkilediğini göstermektedir (Durand Bush, McNeill, Harding ve Dobransky, 2015; Eşigül ve Cenkseven Önder, 2017; Park, Song ve Lee, 2014). Yani algılanan stres düzeyi arttıkça bireyin psikolojik iyi oluş düzeyi düşmektedir. Bireylerin stresli durumlarda problemin çözümüne yönelik aktif çaba göstermeleri problem odaklı baş etme olarak ifade edilirken, duygu odaklı baş etme doğrudan problemin çözümüne yönelik çabadan ziyade ortaya çıkan duygunun yönetilmesine yönelik çabalarını içeren bireyi daha pasif kılan bir yaklaşımdır (Lazarus ve Folkman, 1984). Psikolojik iyi oluşu olumsuz etkileyen stres yaratıcı problemlerin çözümünde, problem odaklı baş etmenin ortaya çıkan duygunun düzenlenmesini sağlayan duygu odaklı problem çözme tarzına göre daha etkili olması (Folkman ve Moskowitz, 2000) araştırmada ortaya çıkan bu sonucun nedeni olarak görülmektedir.

Problem ve duygu odaklı tarzların alt boyutları değerlendirildiğinde, "kendine güvenli yaklaşımın" okul psikolojik danışmanlarının psikolojik iyi oluşlarını pozitif yönde etkilediği görülmektedir. Kendine güvenli yaklaşım stres yaratan problemi planlı, karar verme ve problem çözme becerilerini kullanarak aktif bir şekilde çözmeyi içerir (Folkman, 2013). Okul psikolojik danışmanları sundukları profesyonel yardım hizmetinde danışanlarına, problem çözümünde sorumluluk alma, problemin kaynağını anlama, farkındalık kazanma, problem çözme basamaklarını kullanma, karar verme ve eyleme geçme becerilerini kazandırmaya çalışırlar (Hackney ve Cormier, 2008). Aldıkları eğitim sayesinde bu becerileri edinmiş olan psikolojik danışmanların rol model olma sorumluluğu gereği meslek ve özel hayatlarında bu becerileri sıklıkla kullandıkları söylenebilir. Araştırma kapsamında uygulanan ölçekten elde edilen puanların ortalamaları dikkate alındığında okul psikolojik danışmanlarının sahip oldukları bu becerileri içeren kendine güvenli yaklaşımı kullanmaya daha yatkın oldukları görülmektedir. Okul psikolojik danışmanlarının diğer yaklaşımlara göre daha çok kullanma eğiliminde oldukları kendine güvenli yaklaşımın stres yaratan problemlerin çözümünde etkili olması (Folkman ve Moskowitz, 2000) araştırmanın bu sonucunu açıklar niteliktedir. Problem odaklı başa çıkma tarzının alt boyutlarından iyimserlik ise okul psikolojik danışmanlarının psikolojik iyi oluşlarını negatif yönde etkilemektedir. İyimser yaklaşım bireyin olumlu yaşam olaylarını 
içsel ve kalıcı, olumsuz yaşam olaylarını ise dışsal ve geçici olarak değerlendirmesini içerir (Luthans ve Youssef Morgan, 2004). Yaşanan durumu dişsal kaynaklı ve geçici bir durum olarak değerlendirmek, bireyin gerekli müdahaleleri zamanında yapmamasına ve problemin çözümü noktasında kendine güvenli yaklaşıma göre daha pasif kalmasına neden olmaktadır (Luthans ve diğerleri, 2007). Araştırmanın bu sonucunda, problemlerin çözümünde daha etkin rol alarak, aldıkları eğitim sayesinde edindikleri becerileri kullanma eğiliminde olan psikolojik danışmanların, bu becerilerini kullanmalarını sınırlayan ve kendine güvenli yaklaşıma göre daha pasif kalmalarına neden olan iyimser yaklaşımı kullanmalarının yarattığı çatışmanın neden olduğu düşünülmektedir.

Problem odaklı başa çıkma tarzının bir diğer alt boyutu olan sosyal destek arama ile okul psikolojik danışmanlarının psikolojik iyi oluşları arasında anlamlı bir ilişki bulunmamıştır. Okul danışmanları bulundukları pozisyon gereği idare, öğretmen ve öğrenci kaynaklı her sorun alanının çözümü noktasındadırlar. Dolayısıyla okulda yaşanan birçok sorunla ilgili bilgi sahibidirler. Ancak gerek bağlı oldukları yönetmelikler (MEB, 2020) gerekse mesleki etik ilkelerinin başında gelen gizlilik ilkesi (ACA, 2014) nedeni ile yasal zorunluluklar ile ciddi ve öngörülebilir zarar verme durumları dışında, bu sorunların çözümü noktasında kimseyle paylaşıma girmemektedirler. Gizlilik mesleğin sağlıklı icrası, danışman ve danışan arasındaki terapötik ilişkinin kurulması, güven ve mesleki saygınlığın korunması için gerekli olan ve sadık kalınması gereken etik ilkelerden biridir (Arslan ve diğerleri, 2019). Okul psikolojik danışmanlarının gizlilik ilkesi nedeniyle sorunların çözümünde tek başına hareket etmeleri sosyal destek arama yaklaşımını başa çıkma alternatiflerinin dışında görme eğilimine neden olduğu söylenebilir. $\mathrm{Bu}$ durumun araştırmanın bu sonucu üzerinde etkili olduğu düşünülmektedir. Son olarak yapılan analizlerde duygu odaklı baş etmenin alt boyutlarından çaresiz yaklaşım ve boyun eğici yaklaşımın okul psikolojik danışmanlarının psikolojik iyi oluşlarını yordamadığı sonucuna ulaşılmıştır. Duygu odaklı baş etme, problemi çözmek yerine ortaya çıan duygunun yönetilmesine önem veren geçici bir çözüm olarak değerlendirilmektedir (Lazarus ve Folkman, 1984). Psikolojik danışmanların yaşanan soruna yönelik daha kalıcı çözümler getirme, problemlerin çözümünde daha etkin rol üstlenerek, aldıkları eğitim sayesinde edindikleri becerileri kullanma eğiliminde olmalarının ortaya çıkan bu sonuçta etkili olduğu düşünülmektedir.

Okul psikolojik danışmanlarının psikolojik sermaye düzeyleri ile başa çıkma tarzlarının psikolojik iyi oluşları üzerindeki etkisini inceleyen bu çalışmada bazı sınırlılıklar söz konusudur. Öncelikli olarak Türkiye çapında çalışan okul psikolojik danışmanlarının sayısı düşünüldüğünde, bu araştırmanın örneklem sayısı çalışmanın ilk sinırlılığıdır. Sonuçların genellenebilirliğini artırmak için gelecekte yapılacak benzer araştırmaların daha geniş örneklemler üzerinde gerçekleştirilmesi önerilmektedir. Araştırmada verilerin öz bildirime dayalı toplanmış olması araştırmanın bir diğer sınırlılığıdır. Gelecek araştırmalarda görüşme gibi farklı veri toplama yaklaşımları kullanılarak konu derinlemesine ele alınabilir. Psikolojik danışma mesleğinin sağlıklı yürütülmesinde psikolojik danışmanın sahip olması gereken niteliklerden biri olan okul psikolojik danışmanlarının psikolojik iyi oluşları ile ilgili alanda çok fazla çalışma yoktur. Gelecek çalışmalarda bu kavram benzer ve farklı değişkenlerle ele alınıp farklı istatistiksel yaklaşımlarla incelenerek okul psikolojik danışmanlarının psikolojik iyi oluşlarının tüm bileşenlerinin ortaya konulması gereklilik arz etmektedir.

Psikolojik danışmanların mesleki açıdan kendilerini yetkin görmemelerinde, aldıkları eğitimin yetersiz kalmasının (Çokamay ve diğerleri, 2017) ve süpervizyon desteğinden yoksun olmalarının (Aydın ve Odacı, 2020a) etkili olduğu bilinmektedir. Okul psikolojik danışmanlarının mesleki yetkinliklerini bireysel çabaları ile artıracak eğitimlere ulaşmaları, bu eğitimlerin genellikle büyük şehirlerde yapılması, maliyetlerinin yüksek olması nedenleri ile zorlaşmaktadır. Öğretmen yeterliliğini artırmak için öğretmen yetiştirme ve geliştirme genel müdürlüğü (ÖYGM) tarafından verilen hizmetiçi eğitim faaliyetleri ise psikolojik danışmanların çalışma alanlarını kapsayıcı yeterlilikte değildir (ÖYGM, 2021). Üniversitelerin süpervizyon 
yardımı ve destekleyici eğitim programları geliştirerek, mezunlara yönelik eğitimler vermesi, Türkiye'deki birçok ilde Psikolojik Danışma ve Rehberlik bölümü olması dikkate alındığında, okul psikolojik danışmanlarının yetkinliklerini artıracak olan bu eğitimlere ve süpervizyon desteğine ulaşmalarını kolaylaştıracaktır. Ayrıca ÖYGM tarafından gerçekleştirilen hizmet içi eğitimlerin okul psikolojik danışmanlarının çalışma alanlarını ve mesleki yeterliliklerini artıracak nitelikte planlanması da bu ihtiyacın karşılanmasına yardımcı olacaktır. Okul psikolojik danışmanlarının yetkiliklerini artıracak bu gibi çalışmalar psikolojik iyi oluşlarını da olumlu yönde etkileyecektir. Ayrıca mesleğin görev ve sorumluluk alanlarının tam olarak belirlenememiş olması, mesleki etik ilkelere ters düşen görevler verilmesi, okul danışmanlarının iş hayatında sik s1k strese maruz kalmalarına (Culbreth ve diğerleri, 2005; Monteiro Leitner ve diğerleri, 2006) neden olmaktadır. Politika belirleyicilerin bu sonuçları dikkate alarak mesleğin sınırlarını belirlemeye yönelik yasal düzenlemeleri gerçekleştirmesi, mesleğin tanımı ve sorumluluk alanlarını ortaya koyup koruyacak olan meslek odasının kurulması önem arz etmektedir. $\mathrm{Bu}$ düzenlemelerin okul psikolojik danışmanlarının yaşadığı stres faktörlerini azaltıp, geleceğe yönelik iyimser bakış açılarını ve umut düzeylerini yükselterek, psikolojik iyi oluşlarını olumlu yönde etkileyeceği düşülmektedir.

\section{KAYNAKÇA}

American Counseling Association (2014). ACA code of ethics. Erişim adresi: https://www.counseling.org/knowledge-center/ethics

American School Counselor Association. (2010). The professional school counselor and school family community partnerships (position statement). Erişim adresi: https://www.schoolcounselor.org/getmedia/d597c40b-7684-445f-b5ed713388478486/Position-Statements.pdf

Arnau, R., Rosen, D., Finch, J., Rhudy, J. \&Fortunato, V. (2007). Longitudinal effects of hope on depression and anxiety: A latent variable analysis. Journal of Personality, 75(1), 4364.

Arslan, Ü., Karataş, U. ve Dostuoğlu, E. (2019). Psikolojik danışmanlık alanında mevcut ve gelişen etik sorunlar. Mersin University Journal of Education, 15(1), 86-103.

Avey, J. B., Luthans, F., Smith, R. M. \& Palmer, N. F. (2010). Impact of positive psychological capital on employee well-being over time. Journal of Occupational Health Psychology, 15(1), 17-28.

Avey, J. B., Reichard, R. J., Luthans, F. \& Mhatre, K. H. (2011). Meta-analysis of the impact of positive psychological capital on employee attitudes, behaviors, and performance. Human Resource Development Quarterly, 22(2), 127-152.

Aydın, F., Odacı, H. \& Kahveci, H. (2017). School counselors' counseling self-efficacy: An evaluation in terms of life satisfaction and hope. Journal of Human Sciences, 14(4), 46074627.

Aydın, F. \& Odacı, H. (2020a). Life satisfaction of counsellor supervisees: The role of counselling self-efficacy, trait anxiety and trait hope. British Journal of Guidance \& Counselling. Erken Çevrimiçi Yayın.

Aydın, F. \& Odac1, H. (2020b). School counsellors' job satisfaction: What is the role of counselling self-efficacy, trait anxiety and cognitive flexibility? Journal of Psychologists and Counsellors in Schools, 30(2), 202-215.

Baker, J. P. \& Berenbaum, H. (2007). Emotional approach and problem-focused coping: A comparison of potentially adaptive strategies. Cognition and Emotion, 21(1), 95-118. 
Bandura, A. (1977). Self-efficacy: Toward a unifying theory of behavioral change. Psychological Review, 84(2), 191-215.

Baron, R. M. \& Kenny, D. A. (1986). The moderator-mediator variable distinction in social psychological research: Conceptual, strategic, andstatistical considerations. Journal of Personality and Social Psychology, 51(6), 1173-1182.

Carlson, L. \& Kees, N. (2013). Mental health services in public schools: A preliminary study of counselor perceptions. Professional School Counseling, 16(4), 211-221.

Carver, C. S., Scheier, M. F. \& Segerstrom, S. C. (2010). Optimism. Clinical Psychology Review, 30(7), 879-889.

Chang, E. C. (2003). A critical appraisal and extension of hope theory in middle-aged men and women: Is it important to distinguish agency and pathways components? Journal of Social and Clinical Psychology, 22(2), 121-43.

Cohen, J. (1988). Statistical Power Analysis for the Behavioral Sciences (2nd Ed.). Hillsdale, NJ: Lawrence Earlbaum Associates.

Cohn, M. A., Fredrickson, B. L., Brown, S. L., Mikels, J. A. \& Conway, A. M. (2009). Happiness unpacked: Positive emotions increase life satisfaction by building resilience. Emotion, 9(3), 361-368.

Corey, G. (2008). Psikolojik danışma, psikoterapi kuram ve uygulamaları (Çev. T. Ergene). Ankara: Mentis Yayınc1lık.

Culbreth, J. R., Scarborough, J. L., Banks-Johnson, A. \& Solomon, S. (2005). Role stress among practicing school counselors. Counselor Education and Supervision, 45(1), 58-71.

Culver, L. McKinney, B. L. \& Paradise, L.V. (2011). Mental health professionals' experiences of vicarious traumatization in post-Hurricane Katrina New Orleans. Journal of Loss and Trauma, 16(1), 33-42.

Çankır, B. \& Şahin, S. (2018). Psychological well-being and job performance: The mediating role of work engagement. Hitit University Journal of Social Sciences Institute, 11(3), 2549-2560.

Çavmak, D., ve Acar, F. (2020). Pozitif psikolojik sermaye ile performans algısı arasındaki ilişki: Sağlık çalışanları üzerine bir araştırma. İş ve İnsan Dergisi, 7(2), 203-212. https://doi.org/ 10.18394/iid.732944

Çetin, F. \& Basım, H. N. (2012). Organizational psychological capital: A scale adaptation study. Journal of Public Administration, 45(1), 121-137. Erişim adresi: https://www.researchgate.net/publication/288627957_Organizational_Psychological_Cap ital_A_Scale_Adaptation_Study

Çokamay, G., Kapçı, E. G. ve Sever, M. (2017). Okul ruh sağlı̆̆ı hizmetlerinde yaşanan sorunlar: Psikolojik danışmanların görüşleri. Elementary Education Online, 16(4), 13951406.

De Caroli, M. E. \& Sagone, E. (2014). Generalized self-efficacy and well-being in adolescents with high vs. low scholastic self-efficacy. Procedia-Social and Behavioral Sciences, 141, 867-874.

Deci, E. L. \& Ryan, R. M. (2008). Hedonia, eudaimonia, and well-being: An introduction. Journal of Happiness Studies, 9(1), 1-11.

Değirmenci, B. (2019). Kamu çalışanlarının psikolojik dayanıklılık psikolojik iyi olma ilişkisinde iyimserliğin aracilık rolü. Journal of Turkish Social Sciences Research, 4(1), 47-63. Erişim adresi: http://tursbad.hku.edu.tr/tr/pub/issue/44945/532954 
Demirci, İ. (2020). School engagement and well-being in adolescents: Mediating roles of hope and social competence. Child Indicators Research, 13(5), 1573-1595.

Demirtaş, A. S., Baytemir, K. ve Güllü, A. (2018). Pedagojik formasyon öğrencilerinde umut ve mental iyi oluş: Yapılandırmacı düşünmenin aracı rolü. Mersin University Journal of the Faculty of Education, 14(1), 317-331.

Diener, E., Wirtz, D., Tov, W., Kim Prieto, C., Choi, D. W., Oishi, S. \& Biswas Diener, R. (2010). New well-being measures: Short scales to assess flourishing and positive and negative feelings. Social Indicators Research, 97(2), 143-156. Erişim adresi: https://link.springer.com/article/10.1007/s11205-009-9493-y

Duarte, M. E. (2017). Counselling and well-being: on the road to realities. British Journal of Guidance \& Counselling, 45(5), 508-518.

Ducharme, L. J., Knudsen, H. K. \& Roman, P. M. (2007). Emotional exhaustion and turnover intention in human service occupations: The protective role of coworker support. Sociological Spectrum, 28(1), 81-104.

Duman, N., Göksu, P., Köroğlu, C. ve Talay, A. (2020). Üniversite öğrencilerinde mental iyi oluş ile psikolojik dayanıklılık ilişkisi. Life Skills Journal of Psychology, 4(7), 9-17.

Durand Bush, N., McNeill, K., Harding, M. \& Dobransky, J. (2015). Investigating stress, psychological well-being, mental health functioning, and self-regulation capacity among university undergraduate students: Is this population optimally functioning? Canadian Journal of Counselling and Psychotherapy, 49(3), 253- 274. Erişim adresi: https://cjcrcc.ucalgary.ca/article/view/61066

Dysvik, E., Natvig, G. Eikeland, O. \& Lindstrom, T. (2005). Coping with chronic pain. International Journal of Nursing Studies, 42(3), 297-305.

Eşigül, E. ve Cenkseven Önder, F. (2017). Üniversite öğrencilerinde stres ve psikolojik iyi olma: Sosyal problem çözmenin aracı ve düzenleyici rolü. Journal of Human Sciences, 14(1), 803-818. Erişim adresi: https://www.jhumansciences.com/ojs/index.php/IJHS/article/view/4275

Field, A. (2013) Discovering statistics using IBM SPSS statistics: And sex and drugs and rock " $N$ " roll (4th ed.). Los Angales: Sage.

Fletcher, J. (2018). Crushing hope: Short term responses to tragedy vary by hopefulness. Social Science \& Medicine, 201, 59-62.

Folkman, S. (2013). Stress, coping, and hope. In Psychological aspects of cancer. New York: Springer.

Folkman, S. \& Lazarus, R. S. (1980). An analysis of coping in a middle-aged community sample. Journal of Health and Social Behavior, 21(3), 219-239.

Folkman, S. \& Moskowitz, J. T. (2000). Positive affect and the other side of coping. American Psychologist, 55(6), 647-654.

Folkman, S. \& Moskowitz, J. T. (2007). Positive affect and meaning-focused coping during significant psychological stress. In The Scope of Social Psychology: Theory and Applications (pp. 193-208). Psychology Press Taylor \& Francis Group.

Fraenkel, J. R., Wallen, N. E. \& Hyun, H. H. (2012). How to design and evaluate research in education (8th ed.). New York: McGraw-Hill.

Frankham, C., Richardson, T. \& Maguire, N. (2020). Do locus of control, self-esteem, hope and shame mediate the relationship between financial hardship and mental health? Community Mental Health Journal, 56(3), 404-415. 
Göçen, A., (2019). Öğretmenlerin yaşam anlamı, psikolojik sermaye ve cinsiyetinin psikolojik iyi oluşlarına etkisi. Cumhuriyet International Journal of Education, 8(1), 135-153.

Gustems Carnicer, J. \& Calderón, C. (2013). Coping strategies and psychological well-being among teacher education students: Coping and well-being in students. European Journal of Psychology of Education, 28(4), 1127-1140.

Hackney, H. ve Cormier, S. (2008). Psikolojik danışma ilke ve teknikleri: Psikolojik yardım süreci el kitabı (Çev. T. Ergene \& S. Aydemir Sevim). Ankara: Mentis Yayıncılık.

Hair, J. F. J, Black, W. C., Babin, B. J. \& Anderson, R. E. (2010). Multivariate data analysis (7th ed.). New Jersey: Pearson Prentice Hall.

Hernández Varas, E., Labrador Encinas, F. J. \& Méndez Suárez, M. (2019). Psychological capital. work satisfaction and health self-perception as predictors of psychological wellbeing in military personnel. Psicothema, 31(3), 277-283.

Holdcraft, C. \& Williamson, C. (1991). Assessment of hope in psychiatric and chemically dependent patients. Applied Nursing Research, 4(3), 129-134.

Huppert, F. A. (2009). Psychological well-being: Evidence regarding its causes and consequences. Applied Psychology: Health and Well-Being, 1(2), 137-164.

Kaba, İ. ve Keklik, İ. (2016). Öğrencilerin üniversiteye uyumlarında psikolojik dayanıklılık ve psikolojik belirtiler. Hacettepe Journal of Educational Research, 2(2), 98-113.

Keldal, G. (2015). Warwick Edinburgh mental well-being scale in Turkish: Validity and reliability study. The Journal of Happiness \& Well-Being, 3(1), 103-115. Erişim adresi: https://www.journalofhappiness.net/frontend/articles/pdf/v03i01/Psikolojikiyioluss.pdf

Keleş, H. N. (2017). The relationship between meaningful work and psychological well-being. The Journal of Happiness \& Well-Being, 5(1), 154-167. Erişim adresi: http://www.journalofhappiness.net/frontend/articles/pdf/v5i1/anlamli-ispdf.pdf

Kılınç, M. (2017). Psikolojik iyi oluşun yordayıcıları olarak öz yeterlik ve etkileşim kaygısı. The Journal of International Education Science, 4(13), 207-216.

Kim, N. \& Lambie. G. W. (2018). Burnout and implications for professional school counselors. The Professional Counselor, 8(3), 277-294.

King White, D. L. (2019). The role of school counselors in supporting mental health models in schools. Journal of School Counseling, 17(4), 1-24. Erişim adresi: http://www.jsc.montana.edu/articles/v17n4.pdf

Kumcağız, H., Şahin, C., Alakuş, K. ve Akbaş, M. (2017). Yeme tutumlarını yordama da umut ve olumsuz düşüncelerin rolü. International Journal of Eurasia Social Sciences, 8(29), 939-954.

Kylma, J. (2005). Dynamics of hope in adults living with HIV/AIDS: A substantive theory. Journal of Advanced Nursing, 52(6), 620-630.

Lawson, G. \& Myers, J. E. (2011). Wellness, professional quality of life, and career-sustaining behaviors: What keeps us well? Journal of Counseling \& Development, 89(2), 163-171.

Lazarus, R. S. \& Folkman, S. (1984). Psychological stress and the coping process. New York: Springer.

Li, Y. (2018). Building well-being among university teachers: the roles of psychological capital and meaning in life. European Journal of Work and Organizational Psychology, 27(5), $1-9$. 
Lizano, E. L. (2015) Examining the impact of job burnout on the health and well-being of human service workers: A systematic review and synthesis. Human Service Organizations: Management. Leadership \& Governance, 39(3), 167-181.

Long, K. N. G., Kim, E. S., Chen, Y., Wilson, M. F., Worthington Jr, E. L. \& VanderWeele, T. J. (2020). The role of hope in subsequent health and well-being for older adults: An outcome-wide longitudinal approach. Global Epidemiology. Erken Çevrimiçi Yayın.

Luthans, F. \& Youssef-Morgan, C. (2004). Human, social and now positive psychological capital management. Organizational Dynamics, 33(2), 143-160.

Luthans, F., Avolio, B.J., Avey, J. B. \& Norman, S. M. (2007). Positive psychological capital: Measurement and relationship with performance and satisfaction. Personnel Psychology, 60(3), 541-572.

Luthans, F., Vogelgesang, G. R. \& Lester, P. B. (2006). Developing the psychological capital of resiliency. Human Resource Development Review, 5(1), 25-44.

Luthans, F., Youssef Morgan, C. M. \& Avolio. B. (2015). Psychological capital and beyond. New York: Oxford University Press.

Malkoç, A. ve Yalçın, İ. (2015). Üniversite öğrencilerinde psikolojik dayanıklılık, sosyal destek, başa çıkma ve iyi oluş arasındaki ilişkiler. Turkish Journal of Psychological Counseling and Guidance, 5(43), 35-43. Erişim adresi: https://dergipark.org.tr/tr/pub/tpdrd/issue/21463/230060

Mayordomo Rodríguez, T., Meléndez Moral, J. C., Viguer Segui, P. \& Sales Galán, A. (2015). Coping strategies as predictors of well-being in youth adult. Social Indicators Research, $122(2), 479-489$.

McCarthy, C., Kerne, V. V. H., Calfa, N. A., Lambert, R. G. \& Guzmá n, M. (2010). An exploration of school counselors' demandsand resources: Relationship to stress. biographic. and caseloadcharacteristics. Professional School Counseling, 13(3), 146-158.

Milli Eğitim Bakanlığı (2020). Millî eğitim bakanlığı rehberlik ve psikolojik danışma hizmetleri yönetmeliği. Resmi Gazete, 31213. Erişim adresi: https://www.resmigazete.gov.tr/eskiler/2020/08/20200814-2.htm

Monteiro Leitner, J., Asner Self, K.K., Milde, C., Leitner, D.W. \& Skelton, D. (2006). The role of the rural school counselor: Counselor in training and principal perceptions. Professional School Counseling, 9(3), 248-251.

Mullen, P. R. \& Gutierrez. D. (2016). Burnout. perceived stress. anddirect student services among school counselors. The Professional Counselor, 6(4), 344-359.

O'Connor, K., Muller Neff, D. \& Pitman, S. (2018). Burnout in mental health professionals: A systematic review and meta-analysis of prevalence and determinants. European Psychiatry, 53, 74-99.

O'Connor, M. \& Coyne, J. (2016). School-based counselling service use: A year in the life of a school counselling department. Journal of Psychologists and Counsellors in Schools, 27(2), 251-261.

Öğretmen Yetiştirme ve Geliştirme Genel Müdürlüğü. (2021). 2021 yılı öğretmenlerin hizmetiçi eğitim planı. Erişim adresi: http://oygm.meb.gov.tr/www/icerik_goruntule.php?KNO=28

Park, H. \& Jeong, D. Y. (2015). Psychological well-being, life satisfaction, and self-esteem among adaptive perfectionists, maladaptive perfectionists, and nonperfectionists. Personality and Individual Differences, 72, 165-170. 
Park, N., Song, H. \& Lee, K. M. (2014). Social networking sites and other media use, acculturation stress, and psychological well-being among East Asian college students in the United States. Computers in Human Behavior, 36, 138-146.

Parmaksız, I. ve Gök, A. (2018). Okul psikolojik danışmanlarının psikolojik danışma ve rehberlik hizmetlerinin yürütülmesinde karşılaştıkları güçlükler. Mehmet Akif Ersoy University Journal of Education Faculty, 47, 247-265.

Passmore, S., Hemming, E., McIntosh, H. C. \& Hellman, C. M. (2020). The relationship between hope, meaning in work, secondary traumatic stress, and burnout among child abuse pediatric clinicians. The Permanente Journal, 24(1), 29-34.

Perusse, R., Goodnough, G., Donegan, J. \& Jones, C. (2004). Perceptions of school counselors and school principals about the national standards for school counseling programs and transforming school counseling initiative. Professional School Counseling, 7(3), 152-161.

Ryff, C. D. (1989). Happiness is everything. or is it? Explorations on the meaning of psychological well-being. Journal of Personality and Social Psychology, 57(6), 10691081.

Ryff, C. D. \& Keyes, C.L.M. (1995). The structure of psychological well-being revisited. Journal of Personality and Social Psychology, 69(4), 719-727.

Ryff, C. D. \& Singer, B. H. (2006). Know thyself and become what you are: A eudaimonic approach to psychological well-being. Journal of Happiness Studie, 9(1), 13-39.

Sagone, E. \& Caroli, M. E. (2014). A correlational study on dispositional resilience, psychological well-being, and coping strategies in university students. American Journal of Educational Research, 2(7), 463-471.

Satıcı, S. A. ve Deniz, M. E. (2017). Mizahla başa çıkma ve iyilik hali: Psikolojik sağlamlık ve iyimserliğin aracıllk rolünün incelenmesi. Elementary Education Online, 16(3), 13431356.

Shorey, H. S., Little, T. D., Snyder, C. R., Kluck, B. \& Robitschek, C. (2007). Hope and personal growth initiative: A comparison of positive, future-oriented constructs. Personality and Individual Differences, 43(7), 1917-26.

Shorosh, S. \& Berkovich, I. (2020). The relationships between workgroup emotional climate and teachers' burnout and coping style. Research Papers in Education. Erken Çevrimiçi Yayin.

Snyder, C. R. (2002). Hope theory: Rainbows in the mind. Psychological Inquiry, 13(4), 249275.

Snyder, C. R. \& Cheavens, J. (2000). A hope-based group treatment for depressed older adult outpatients. Physical Illness and Depression in Older Adults: A Handbook of Theory, Research, and Practice. (Ed. Gail M. Williamson, David R. Shaffer \& Patricia A. Parmelee). Kluwer Academic Publishers.

Snyder, S. R., Feldman, D. B., Shorey, H. S. \& Rand, K. L. (2002). Hopeful choices: A school counselor's guide to hope theory. Professional School Counseling, 5(5), 298-306.

Soykan, A., Gardner, D. \& Edwards, T. (2019). Subjective wellbeing in New Zealand teachers: An examination of the role of psychological capital. Journal of Psychologists and Counsellors in Schools, 1-9.

Stapleton, P., Garby, S. \& Sabot, D. (2020). Psychological distress and coping styles in teachers: A preliminary study. Australian Journal of Education, 4(2),127-146. 
Sahin N. ve Durak, A. (1995). Stresle başa çıkma tarzları ölçeği: Üniversite öğrencileri için uyarlaması [Stress coping styles scale, adaptation for university students]. Turkish Journal of Psychology, 10(34), 56-73. Erişim adresi: https://toad.halileksi.net/sites/default/files/pdf/stresle-basacikma-tarzlari-olcegi-toad.pdf

Tabachnick, B. G. \& Fidell, L. S. (2013). Using multivariate statistics (6th ed.). Boston: Allyn and Bacon.

Tan, S. Y. \& Chou, C. C. (2017). Supervision effects on self-efficacy, competency, and job involvement of school counsellors. Journal of Psychologists and Counsellors in Schools, 28(01), 18-32.

Tennant, R., Hiller, L., Fishwick, R., Platt, S., Joseph, S., Weich, S., ... \& Stewart-Brown, S. (2007). The Warwick Edinburgh mental well-being scale (WEMWBS): Development and UK validation. Health and Quality of Life Outcomes, 5(1), 1-13.

The World Health Organization. (2004). The World Health Report 2004: Changing History. Annex Table 3: Burden of disease in DALYs by cause, sex, and mortality stratum in WHO regions. Erişim adresi: www.who.int/whr/2004/annex/ en/index.html.

Tummers, J. (2016). The relationship between coping and job performance. Journal of Public Administration Research and Theory, 27(1), 1-13.

Vidwans, S. S. \& Raghvendra, P. (2016). A study meaningful work, hope and meaning in life in young professional artists. Indian Journal of Positive Psychology, 7(4), 469-471.

Wong, S. S. \& Lim, T. (2009). Hope versus optimism in Singaporean adolescent: Contribution to depression and life satisfaction. Personality and Individual Differences, 46(5-6), 648652.

Wright, T. A. \& Cropanzano. R. (2000). Psychological well-being and job satisfaction as predictors of job performance. Journal of Occupational Health Psychology, 5(1), 84-94.

Yalçın, İ. \& Malkoç, A. (2015). The relationship between meaning in life and subjective wellbeing: Forgiveness and hope as mediators. Journal of Happiness Study, 16(4), 915-929.

Young, M. E. \& Lambie, G. W. (2007). Wellness in school and mental health systems: Organizational influences. The Journal of Humanistic Counseling, Education and Development, 46(1), 98-113.

Youssef Morgan, C. \& Luthans, F. (2007). Positive organizational behavior in the workplace. Journal of Management, 33(5), 774-800.

Youssef Morgan, C. \& Luthans. F. (2015). Psychological capital and well-being. Stress and Health, 31(3), 180-8.

\section{EXTENDED ABSTRACT}

\section{Introduction}

School counselors are simultaneously responsible for basic studies such as planning, orientation, consultation, getting to know the student, counseling, referral and monitoring (Ministry of National Education [MEB], 2020). Depending on the attitudes of school administrators, school counselors are sometimes assigned inconsistent roles such as attending lectures, keeping watch, and secretariat, which are not included in the job descriptions (Culbreth et al., 2005). These practices, attitudes and behaviors that are outside the ethical rules; it can be argued that school counselors have a negative impact on their psychological well-being and prevent them from being successful in their duties. Psychological well-being is an important element for school counselors who provide multi-faceted services related to child and 
adolescent psychology, and it is a necessity for counselors to protect their own psychological health. Counselors with a high level of psychological well-being and good mental health are more likely to help their clients (Lawson \& Myers, 2011; Tan \& Chou, 2017), and clients may be harmed when this well-being is not maintained. Psychological capital, which defines an individual's positive psychological development status (Luthans et al., 2015); it includes the sum of sub-factors consisting of hope, optimism, resilience and self-efficacy (Luthans et al., 2007). Psychological counselors working in schools are faced with many problems and the clients' continuation of their work depends on their ability to cope with the problems and negative emotions they encounter. Coping includes conscious and deliberate actions towards problems (Lazarus \& Folkman, 1984). It can be stated that the coping styles used by psychological counselors, who frequently encounter stressful situations due to working conditions, and their psychological well-being shaped by their effects, will affect the quality of the service they provide.

\section{Methods}

The sample of this study, which was designed according to the relational research model, consists of a total of 214 psychological counselors, 157 women and 57 men, who participated voluntarily. The data in the study were obtained by using the Demographic Information Form, the Mental Well-Being Scale, the Organizational Psychological Capital Scale and the Styles of Coping with Stress Scale. Before starting the study, approval was obtained from the Trabzon University Social and Human Sciences Ethics Committee, and then the data form was sent to the participants online. Before the analysis of the data collected within the scope of this research, missing value, extreme value and normal distribution analyzes were performed. Pearson product-moment correlation technique and hierarchical regression analysis were used in the analysis of the data.

\section{Results}

As a result of the analysis, it was determined that optimism, hope and self-efficacy, which are the sub-dimensions of psychological capital, contributed significantly to the model (\%.46), while the contribution of another sub-dimension, psychological resilience, to the model was insignificant. In the second stage, problem and emotion-oriented styles were added to the model and it was determined that the contribution of the self-confident approach and optimistic approach, which are sub-dimensions of the problem-oriented style, to the model was statistically significant (\%.03). Finally, it was determined that the contribution of the helpless and submissive attitude, which are the sub-dimensions of emotion-focused coping, to the model was statistically insignificant.

\section{Discussion and Conclusion}

According to the results of the research, optimism, one of the sub-dimensions of psychological capital, makes a significant positive contribution to the well-being of school psychological counselors. This result of the study is similar to many studies in the literature (Avey et al., 2010; Değirmenci, 2019; Diener et al., 2010; Göçen, 2019; Satış \& Deniz, 2017). It is thought that it is a natural result that the counselors adopt an optimistic attitude that motivates the person to cope with problem areas, enables them to perceive the problems and personal mistakes as temporary and changeable instead of seeing them as inadequacy, and makes them realistic and eager to reach their goals, positively affecting their psychological well-being. Another finding of the study is that hope positively predicts psychological well-being, and this finding has been supported by many studies in the literature (Chang, 2003; Demirci, 2020; Demirtaş et al., 2018; Shorey et al., 2007; Yalçın and Malkoç, 2015). According to another result of the study, the self-efficacy of school psychological counselors positively predicts their psychological well-being. In the literature review, it was seen that there are studies supporting this result of the research (De Caroli and Sagone, 2014; Göçen, 2019; Kılınç, 2017). This finding can be explained by the fact that school counselors who are competent in the field will 
experience less ethical conflict and their psychological well-being will be at a high level due to their healthier and more effective conduct of their professional work. Another finding is that resilience has no significant effect on the well-being of school counselors. Although this result is not supported by some studies in the literature (Değirmenci, 2019; Kaba \& Keklik, 2016), although there are a limited number of studies supporting this finding of the study, the researchers explain this situation in their studies due to the insufficient sample size. When the effects of coping styles on psychological well-being are examined; while both self-confident and optimistic approach sub-dimensions of problem-focused coping have a low-level significant effect on psychological counselors' well-being, the effect of helpless and submissive approach, one of the sub-dimensions of emotion-focused coping, is not significant. The reason for this result revealed in the research is that problem-focused coping is more effective than emotionfocused problem-solving style, which regulates the resulting emotion, in solving stressors that negatively affect psychological well-being (Folkman \& Moskowitz, 2000). 